\title{
ANALISIS KERAGAMAN GENETIK ISOLAT Corynespora cassiicola (Berk \& Curt) WEI. DI INDONESIA MENGGUNAKAN MARKER ISSR (INTER SIMPLE SEQUENCE REPEAT)
}

\author{
Genetic Variability Analysis of Corynespora cassiicola (Berk \& Curt) Wei. Isolates \\ in Indonesia using ISSR (Inter Simple Sequence Repeat) Markers
}

Misbakhul MUNIR, Heru SURYANINGTYAS, dan KUSWANHADI

Balai Penelitian Sembawa, Pusat Penelitian Karet

Jalan Raya Palembang - P. Balai KM 29, PO BOX 1127 Palembang 30001

Diterima tgl 9 Juli 2012 / Disetujui tgl 20 September 2012

\begin{abstract}
Corynespora Leaf Fall Disease caused by Corynespora cassiicola (Berk \& Curt) Wei is one of most important diseases in rubber plantation. It is noted that Hevea clones have become more susceptible to the disease and the susceptibility to the pathogen varies in different geographic regions. The problem may occur because of the evolution of pathogen that can generate new races with more virulent nature. Thus, the information on the inherent variability of the pathogen is really needed. A research was done to find out the genetic diversity, and infection severity of Corynespora isolates. The material used in this research was Corynespora cassiicola isolates from Lampung, Bengkulu, South Sumatera, Jambi, North Sumatera, West Kalimantan, and Central Java. The procedurs of this researcch were isolates preparation, the DNA extraction performed using modified CTAB method PCR analysis, using ISSR and data analysis made using UPGMA in NTSYS computer program. The results of genetic diversity analisis on isolates of Corynespora cassiicola obtained from seven rubber central areas in Indonesia by using ISSR markers produced four groups (4 races) of C. cassiicola, group A (Race 1) the isolates from Bengkulu; group $B$ (Race 2) covering isolates from Lampung and North Sumatera; group C (Race 3) covering isolates from West Kalimantan; South Sumatera and Jambi; and group D (Race 4) the isolates from Central Java. The detached leaf assay's results showed that Corynespora isolates residing in the same group based on the results of genetic analysis also had the same infection (pathogenicity) on rubber leaves. Isolates from Central Java (CJT) showed the highest average rate of infection
\end{abstract}

(pathogenicity) compared with the other isolates. The lowest infections rate of the seven isolates was found in clones RRIM 712 and IRR 5, whereas the highest one was in $B P M 24$ and PR 255 clones.

Keywords: Hevea brasiliensis, genetic variability analysis, Corynespora cassiicola, ISSR

Abstrak
Penyakit Gugur Daun Corynespora
yang disebabkan oleh patogen Corynespora
cassiicola (Berk \& Curt) Wei., merupakan
salah satu penyakit penting pada tanaman
karet (Hevea brasiliensis). Klon-klon karet
yang semula bersifat moderat terhadap
serangan jamur ini, setelah beberapa tahun
menjadi rentan dan terserang hebat. Hal
tersebut diduga karena evolusi patogen
menghasilkan ras baru yanglebih merusak.
Oleh karena itu, informasi yang berkaitan
dengan variabilitas patogen sangat
diperlukan. Suatu penelitian dilakukan
untuk mengetahui keragaman genetik,
kekerabatan dan tingkat infeksi isolate C.
cassiicola. Bahan yang dipakai dalam
penelitian ini adalah isolat Corynespora
cassiicola dari tujuh daerah sentra
perkebunan karet Indonesia yaitu
Lampung, Bengkulu, Sumatera Selatan,
Jambi, Sumatera Utara, Kalimantan Barat,
dan Jawa Tengah. Prosedur kerja dalam
penelitian ini meliputi penyiapan kultur
isolat, ekstraksi DNA Corynespora
cassiicola menggunakan metode modifikasi
CTAB, analisis PCR dengan analisis data
menggunakan UPGMA dalam program
NTSYS, dan uji kelayuan daun
menggunakan metode Nghia. Hasil analisis


keragaman genetik isolat Corynespora cassiicola asal tujuh wilayah sentra karet di Indonesia menggunakan marker ISSR menghasilkan empat kelompok (4 ras) C. cassiicola, kelompok A (Ras 1) yaitu isolat asal Bengkulu, kelompok B (Ras 2) meliputi isolat asal Lampung dan Sumatera Utara, kelompok C (Ras 3) meliputi isolat asal Kalimantan Barat, Sumatera Selatan dan Jambi, dan kelompok D (Ras 4) yaitu isolat asal Jawa Tengah. Hasil uji kelayuan daun menunjukkan bahwa isolat-isolat Corynespora yang berada pada kelompok yang sama berdasarkan hasil analisis genetik, juga mempunyai tingkat infeksi (patogenitas) yang sama terhadap beberapa daun karet yang diuji. Isolat asal Jawa tengah (CJT) mempunyai rata-rata tingkat infeksi (patogenitas) tertinggi dibanding isolat yang lainnya. Tingkat infeksi terendah dari tujuh isolat adalah pada klon RRIM 712 dan IRR 5, sedangkan tertinggi terdapat pada klon BPM 24 dan PR 255.

Kata kunci: Hevea brasiliensis, analisis keragaman genetik, Corynespora cassiicola, ISSR

\section{PENDAHULUAN}

Penyakit Gugur Daun Corynespora (PGDC) yang disebabkan oleh patogen Corynespora cassiicola (Berk \& Curt) Wei., merupakan salah satu penyakit penting pada tanaman karet (Hevea brasiliensis). Penyakit ini semakin penting setelah klonklon karet yang sebelumnya bersifat moderat dilaporkan menjadi rentan dan terserang hebat setelah beberapa tahun kemudian (Sinulingga et al., 1996). Selain itu, klon-klon karet juga menjadi lebih rentan terhadap variasi patogen yang berasal dari wilayah geografi yang berbeda (Sinulingga et al., 1996). Hal tersebut, memunculkan dugaan adanya ras fisiologi C. cassiicola yang berbeda yang menginfeksi tanaman karet dan/atau terjadi evolusi patogen yang menghasilkan ras baru (Nghia etal., 2007).

Dewasa ini marker molekuler telah luas dipergunakan untuk menentukan karakteristik gen dari berbagai organisme, termasuk jamur, tumbuhan, dan hewan. Penemuan Polymerase Chain Reaction (PCR) mengawali penemuan marker molekuler generasi kedua yang lebih cepat dan murah yang diperoleh dari teknik dasar PCR. Beberapa keberhasilan penggunaan teknik dasar PCR telah dilaporkan untuk mengidentifikasi jamur patogen pada tingkat taksonomi yang lebih rendah daripada spesies (Gil-Lamaignere et al., 2003). Pada penelitian karet, Randomly Amplified Polymorphic DNA (RAPD) telah banyak digunakan untuk identifikasi dan klasifikasi isolat-isolat $C$. cassiicola yang berbeda (Darmono et al., 1996; Situmorang, 2002), namun kelemahan dari RAPD adalah hasil yang tidak sama jika dilakukan perulangan dengan metode yang sama, baik antar laboratorium atau dalam laboratorium yang sama pada waktu yang berbeda terutama dengan mesin yang berbeda (low reproducibility) (Nghia et al., 2007). Inter Simple Sequence Repeat (ISSR) adalah teknik dasar PCR lainnya yang hampir sama dengan teknik RAPD, namun pada ISSR sekuen primer didisain dari daerah microsatelite dan menggunakan suhu marker annealing yang lebih tinggi daripada marker RAPD yang mana dapat menghasilkan produk PCR yang mempunyai konsistensi tinggi (Nghia et al., 2007). Beberapa penelitian telah membuktikan bahwa ISSR berhasil diterapkan dalam identifikasi jamur patogen (Burgess et al., 2001). Oleh karena itu, teknik ini dipilih dalam penelitian ini untuk menganalisis polimorfisme tujuh isolat Corynespora yang berasal dari Lampung, Bengkulu, Sumatera Selatan, Jambi, Sumatera Utara, Kalimantan Selatan, dan Jawa Tengah.

Beberapa ras C. cassiicola yang menginfeksi tanaman karet telah diidentifikasi dan kekerabatan genetik antar isolat telah diketahui (Darmono et al., 1996). Sebagai hasilnya, klon-klon baru untuk rekomendasi harus diseleksi berdasarkan sifat ketahanannya terhadap serangan $C$. cassiicola (Ramli et al., 1996). Oleh karena itu, informasi yang berkaitan dengan variabilitas patogen sangat diperlukan (Nghia et al., 1996) dan beberapa penelitian telah membuktikan bahwa ISSR berhasil diterapkan dalam identifikasi jamur patogen (Burgess et al., 2001).

Tujuan penelitian ini adalah untuk mengetahui keragaman genetik, kekerabatan, dan tingkat infeksi isolat C. cassiicola 
yang berasal dari 7 daerah sentra perkebunan karet Indonesia, yaitu Lampung, Bengkulu, Sumatera Selatan, Jambi, Sumatera Utara, Kalimantan Selatan, dan Jawa Tengah berdasarkan pita polimorfisme yang terbentuk dari teknik dasar PCR menggunakan marker ISSR.

\section{BAHAN DAN METODE}

Biakan C. cassiicola yang digunakan pada penelitian ini adalah tujuh isolat $C$. cassiicola dalam media PDA yang berasal dari sentra perkebunan karet Indonesia dalam bentuk kepingan berdiameter $0,5 \mathrm{~cm}$ dan masing-masing kepingan dimasukkan ke dalam $100 \mathrm{ml}$ media cair sari kentang sukrosa $(500 \mathrm{ml}$ ekstrak kentang, $500 \mathrm{ml}$ aquades, $30 \mathrm{~g}$ sukrosa). Biakan diinkubasi selama 7 hari pada suhu $\geq 25^{\circ} \mathrm{C}$ di atas alat pengocok (shakker) dengan kecepatan 80 rpm. Miselia isolat diambil dan dicuci 2 kali dengan aquades steril dengan penyaring 2 lapis kain kasa (Modifikasi Situmorang, 2002).

\section{Ekstraksi DNA}

Ekstraksi DNA dilakukan menggunakan metode modifikasi CTAB yang diambil dari Situmorang (2002) yaitu, miselia sebanyak 1 gram dari masing-masing isolat dilumatkan dengan $\mathrm{N}_{2}$ cair dalam mortar sampai halus. Tepung miselia tersebut dimasukkan ke dalam tabung $(16 \mathrm{ml})$ yang berisi buffer [(12,6 ml NaCl 5 M, 2 ml EDTA $0,5 \mathrm{M}$ (pH 8), $5 \mathrm{ml}$ Tris HCl $1 \mathrm{M}(\mathrm{pH} \mathrm{8,0),} 10 \mathrm{ml}$ CTAB $10 \%, 20,4 \mathrm{ml}$ akuabides)]. Campuran dikocok dengan vorteks kemudian diinkubasi pada $65^{\circ} \mathrm{C}$ selama 30 menit. Ke dalam campuran ditambahkan lagi $($ kloroform + isoamil alkohol $=24: 1)+$ fenol = 1 : 1 kemudian dikocok dengan vorteks dan disentrifus $11.000 \mathrm{rpm}$ selama 15 menit. Larutan bagian atas tabung (supernatan) diambil dan dimasukkan ke dalam tabung sentrifus. Ditambahkan (kloroform + isoamil alkohol $=24: 1$ ) ke dalam supernatan dan disentrifus lagi $11.000 \mathrm{rpm}$ selama 5 menit. Supernatan diambil dan ditambahkan isopropanol dingin, digoyang pelan kemudian dimasukkan ke dalam freezer selama 30 menit. Larutan disentrifus lagi dalam 11.000 rpm selama 15 menit, cairan dibuang dan pelet diambil. Kemudian pelet dicuci dengan etanol (70\%) dingin, dan disentrifus lagi dalam 11.000 rpm selama 15 menit kemudian dikeringkan dalam kondisi vakum. Pelet DNA yang diperoleh dilarutkan dalam $1 \mathrm{ml}$ buffer TE [(Tris $\mathrm{HCl} 10 \mathrm{mM}(\mathrm{pH}$ 8,0), EDTA $1 \mathrm{mM}$ )]. RNA (ribonucleic acid) dihilangkan dengan menambahkan RNAse (10 $\mu \mathrm{g} / \mathrm{ml})$ ke dalam 0,5 ml DNA dan diinkubasi pada suhu $37^{\circ} \mathrm{C}$ selama satu jam. $\mathrm{Ke}$ dalam larutan ditambahkan etanol absolut $1 \mathrm{ml}$, diaduk perlahan, diinkubasi lagi pada suhu $4{ }^{\circ} \mathrm{C}$ selama 0,5 jam, kemudian disentrifus $11.000 \mathrm{rpm}$ selama 2 menit. Supernatan dibuang dan pelet DNA dicuci dengan etanol $70 \%$ dingin sebanyak $500 \mu 1 \mathrm{TE}$ dan disimpan pada $4^{\circ} \mathrm{C}$. Sebelum disimpan, kemurnian dan total DNA tiap contoh ditentukan dengan spektofotometer atau running gel.

Kualitas DNA diuji dengan elektroforesis gel agarose 0,8\%. Kemurnian DNA dilihat dengan menggunakan UV spektrofotometer pada rasio panjang gelombang 260 nm dan $280 \mathrm{~nm}$ dan konsentrasi DNA pada panjang gelombang $260 \mathrm{~nm}$ dengan $\mathrm{OD}=1$ ekivalen dengan sekitar $50 \mu \mathrm{g} / \mathrm{mL}$ DNA (Sambrook et al., 1989).

\section{Analisis PCR dengan Inter Simple Sequence Repeat (ISSR)}

Berdasarkan kestabilan amplifikasi, dalam penelitian ini digunakan 5 primer ISSR, yaitu UBC 826, UBC 828, UBC 835, UBC 840, dan UBC 850. Amplifikasi PCR dilakukan menurut metode William et al. (1990). Amplifikasi PCR dilakukan dalam 25 $\mu \mathrm{l}$ volum reaksi yang terdiri $1,0 \mu \mathrm{L}$ DNA template (10 $\mathrm{ng} / \mu \mathrm{l}) ; 1,5 \mu \mathrm{L} \mathrm{MgCl2} 25 \mathrm{mM}$; 2,5 $\mu \mathrm{L}$ buffer $10 \mathrm{x}, 0,5 \mu \mathrm{L}$ dNTP $10 \mathrm{mM}$; 0,2 $\mu \mathrm{L} 1 \mathrm{U}$ taq DNA polimerase; $17,3 \mu \mathrm{L}$ ddH2O dan masing-masing $1 \mu \mathrm{L}$ primer ISSR.

Amplifikasi dilakukan dengan menggunakan mesin PCR Biometra, denaturasi awal pada $94^{\circ} \mathrm{C}$ selama 5 menit, diikuti dengan 35 siklus (denaturasi pada $94^{\circ} \mathrm{C}$ selama 30 detik, annealing pada $52^{\circ} \mathrm{C}$ sampai dengan $55^{\circ} \mathrm{C}$ selama 1 menit), extension pada $72^{\circ} \mathrm{C}$ selama 2 menit dan extension akhir pada $72^{\circ} \mathrm{C}$ selama 10 menit (Nghia et al., 2007). Semua reaksi PCR dilakukan dengan tiga ulangan untuk memastikan amplifikasinya konsisten. Untuk negatif kontrol, seluruh substrat 
diamplifikasi dengan mix tanpa penambahan DNA.

Produk amplifikasi dipisahkan ukurannya pada $1,2 \%$ gel agarose dalam $1 \mathrm{x}$ buffer TAE $(40 \mathrm{mM}$ Tris, $20 \mathrm{mM}$ asam asetat dan $1 \mathrm{mM}$ EDTA) pada $70 \mathrm{~V}$ selama 45 menit dalam suhu ruangan. Gel diwarnai dengan Ethidium bromide (Nghia et al., 2007). Selanjutnya gel difoto dengan menggunakan Polaroid di bawah UV transiluminator.

\section{Analisis Data}

Fragmen amplifikasi DNA diberi skor 1 jika ada band DNA yang muncul, dan 0 jika tidak ada band DNA. Data matrik biner digunakan untuk analisis indeks similaritas gen (Genetic Similarity Index) dan perbedaan genetik antara populasi patogen. Analisis cluster dilakukan berdasarkan Matriks Similaritas Nei and Li's (Nei dan Li's, 1979) dengan Unweighted Paired Group Method dengan rata-rata aritmatik (UPGMA). Dendogram disusun menggunakan program Numerical Taxonomy and Multivariate Analysis System (NTSYS-pc) versi 1.8 (Rhohlf, 1993).

\section{Uji Kelayuan/Kerusakan Daun di Laboratorium}

Dari hasil analisis cluster, 3 isolat (isolat dari Bengkulu, Sumatera Selatan, dan Jawa Tengah) yang mewakili 3 kelompok ras, yaitu Ras I, Ras II, dan Ras III, dipilih untuk digunakan dalam uji kelayuan/ kerusakan daun 9 klon karet, yaitu klon IRR 107, RRIM 712, dan RRIM 600 untuk mewakili klon yang rentan terhadap Corynespora; klon PB 260, RRIC 100, dan IRR 5 untuk mewakili klon yang moderat terhadap Corynespora; serta klon BPM 24, IRR 118, dan PR 255 untuk mewakili klon yang resisten terhadap Corynespora. Uji kelayuan/kerusakan daun dilakukan kirakira 10-14 hari setelah daun muda karet direndam dalam air dalam petri disk besar dengan bagian permukaan abaksial daun menghadap ke atas. Inokulasi dilakukan dengan meneteskan $10 \mu \mathrm{l}$ suspensi spora Corynespora cassiicola (2000 spora/ml) dari 3 isolat terpilih ke daun dengan 8 titik tetesan per daun. Pengamatan kerusakan/ kelayuan daun diamati 6 hari setelah inokulasi. Infeksi terjadi ketika jaringan daun pada titik inokulasi menjadi berwarna gelap. Keparahan infeksi diberi skor 0 jika tidak ada luka/bercak; 1 jika ada perubahan warna menjadi gelap namun kecil; 2 jika terdapat bercak yang besar tanpa meluas melalui urat-urat daun; 3 jika terdapat bercak yang besar dan meluas pada uraturat daun; 4 jika terdapat bercak yang besar dan menonjol dengan adanya miselium (Nghia et al., 2007).

\section{HASIL DAN PEMBAHASAN}

Hasil running elektroforesis terhadap hasil amplifikasi tujuh DNA Corynespora cassiicola menunjukkan bahwa tidak muncul band DNA pada isolat asal Bengkulu (CBK); Lampung (CLP) dan Kalimantan Barat (CKB) pada kelima primer. Sementara pada isolat asal Jawa Tengah (CJT), band DNA muncul yaitu pada primer UBC 828, UBC 835, dan UBC 840. Sementara itu, band DNA juga muncul isolat asal Sumatera Selatan (CSS), Jambi (CJB) dan Sumatera Utara (CSU) yaitu masing-masing pada primer UBC 828 dan UBC 840.

Mempertimbangkan percobaanpercobaan hasil running elektroforesis yang telah dilakukan sebelumnya, tampak konsisten bahwa hanya 3 dari 5 primer ISSR yang menghasilkan polimorfisme, yaitu primer UBC 828, UBC 835, dan UBC 840, maka dilakukan running elektroforesis terhadap hasil amplifikasi tujuh isolat DNA Corynespora cassiicola CBK, CLP, CKB, CJT, CSS, dan CJB menggunakan ketiga primer tersebut. Hasil perlakuan tersebut menunjukkan hasil seperti pada Gambar 1 .

Berdasarkan analisis cluster UPGMA terhadap hasil running di atas, maka didapatkan dendogram kekerabatan genetik dari ke-7 isolat Corynespora cassiicola, seperti pada Gambar 2.

Berdasarkan dendogram analisis genetik menggunakan primer ISSR menunjukkan bahwa nilai koefisien kemiripan genetik antar isolat Corynespora berkisar antara 0,57 - 0,68 (57 - 68\%) atau keragaman genetik 32 - 43\% (Gambar 2). Pada nilai koefisien kemiripan genetik $57 \%$ terbagi menjadi 2 kelompok yaitu kelompok A berbeda dengan kelompok lainnya (B, C, 




Gambar 1. Running gel elektroforesis hasil amplifikasi DNA C. cassiicola dari tujuh isolat yang berbeda menggunakan primer UBC 828, UBC 835, dan UBC 840

Figure 1.Running gel electrophoresis of C. cassiicola DNA amplification result of from seven different isolates using primer UBC 828, UBC 835 and UBC 840

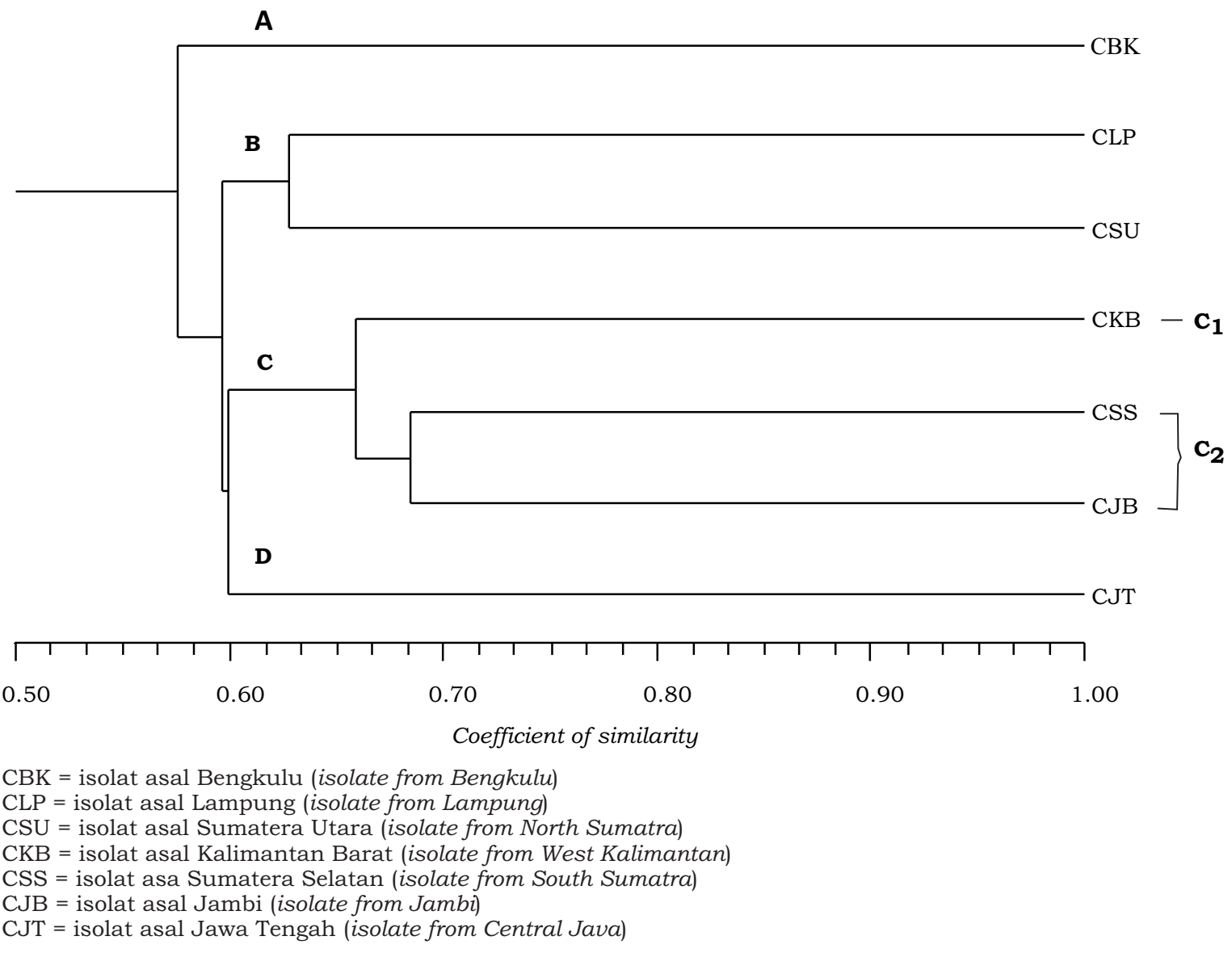

Gambar 2. Dendogram hasil analisis cluster dengan UPGMA menunjukkan hubungan genetik antara tujuh isolat C. cassiicola asal wilayah yang berbeda

Figure 2. Dendogram by UPGMA cluster analysis shows genetic relationships among the seven isolates of $\mathrm{C}$. cassiicola obtained from the different regions 
Tabel 1. Pengelompokan tujuh isolat Corynespora berdasarkan dendogram keragaman genetik Table 1. Grouping seven Corynespora isolates based on genetic diversity dendogram

\begin{tabular}{cccc}
\hline $\begin{array}{c}\text { Kelompok utama } \\
\text { Main group }\end{array}$ & $\begin{array}{c}\text { Sub kelompok } \\
\text { Subgroup }\end{array}$ & $\begin{array}{c}\text { Koefisien kemiripan genetik } \\
\text { Genetic similarity coefficient } \\
\%\end{array}$ & $\begin{array}{c}\text { Isolat } \\
\text { Isolate }\end{array}$ \\
\hline A & - & 57 & CBK \\
B & - & 62,81 & CLP, CSU \\
C & C1 & 65 & CKB \\
& C2 & 68,91 & CSS, CJB \\
D & - & 59 & CJT \\
\hline
\end{tabular}

D), sehingga secara keseluruhan isolat Corynespora yang dianalisis menghasilkan 4 kelompok utama. Kelompok A berjumlah 1 isolat yaitu CBK. Kelompok B berjumlah 2 isolat yaitu CLP dan CSU dengan koefisien kemiripan genetik $62,81 \%$ atau variasi genetik 37,19\%. Kelompok C terdiri dari 3 isolat, dan terbagi dalam 2 sub kelompok. Sub kelompok $\mathrm{C} 1$ yaitu isolat CKB dan sub kelompok C2 terdiri dari isolat CSS dan CJB dengan koefisien kemiripan genetik 68,91\% atau variasi genetik $31,09 \%$. Kelompok D berjumlah 1 isolat yaitu CJT.

Nilai koefisien kemiripan menunjukkan kesamaan individu dalam suatu populasi, semakin tinggi nilai koefisien kemiripan antar individu menunjukkan kekerabatan genetik yang dekat antar individu tersebut. Isolat CSS dan CJB mempunyai koefisien kemiripan yang paling tinggi yaitu 68,91\% (Gambar 2 dan Tabel 1), kedua isolat tersebut menunjukkan kekerabatan genetik yang dekat dibandingkan dengan kekerabatannya dengan isolat yang lain. Hal ini dapat disebabkan oleh wilayah Sumatera Selatan dan Jambi relatif berdekatan secara geografis, sehingga memungkinkan terjadinya aliran gen. Menurut McDonald (1997), faktor yang berperan dan menyebabkan terjadinya perubahan genetika patogen adalah mutasi, rekombinasi, hibridisasi, paraseksual, heterokariosis, migrasi atau aliran gen, besar populasi, dan tekanan seleksi. Matrik kesamaan genetik isolat berdasarkan analisis dengan primer ISSR tersaji dalam Tabel 2.

\section{Tingkat Infeksi Tujuh Isolat Corynespora cassiicola pada Uji Penetesan Spora pada Daun Karet dari Berbagai Klon (Uji Kelayuan Daun)}

Berdasarkan hasil uji kelayuan daun karet dari berbagai klon setelah dilakukan penetesan suspensi spora ke-7 isolat $C$. cassiicola, diketahui bahwa beberapa isolat C. cassiicola mempunyai tingkat infeksi (patogenitas) yang berbeda antara satu dan yang lainnya. Namun uji statistik membuktikan bahwa isolat-isolat yang berada pada kelompok yang sama pada analisis genetik menggunakan marker ISSR (Gambar 3 dan Tabel 1), menunjukkan

Tabel 2. Matriks kesamaan genetik tujuh isolat Corynespora berdasarkan marka ISSR Table 2. Genetic similarity matrix of seven Corynespora isolate based on ISSR markers

\begin{tabular}{lccccccc}
\hline & CBK & CLP & CKB & CJT & CSS & CJB & CSU \\
\hline CBK & 1,0000 & & & & & & \\
CLP & 0,5735 & 1,0000 & & & & & \\
CKB & 0,5890 & 0,5455 & 1,0000 & & & & \\
CJT & 0,5793 & 0,6107 & 0,5816 & 1,0000 & & & \\
CSS & 0,5695 & 0,5109 & 0,6667 & 0,5890 & 1,0000 & & \\
CJB & 0,6207 & 0,6565 & 0,6525 & 0,6286 & 0,6849 & 1,0000 & \\
CSU & 0,5185 & 0,6281 & 0,5649 & 0,5846 & 0,6471 & 0,6462 & 1,0000 \\
\hline
\end{tabular}


tingkat infeksi (patogenitas) yang tidak berbeda nyata. Isolat $C$. cassiicola CSS mempunyai rata-rata tingkat infeksi pada daun uji yang tidak berbeda nyata dengan isolat CJB (berturut-turut 1,70 dan 1,63) (Tabel 3) yang mana kedua isolat tersebut berada pada kelompok yang sama berdasarkan analisis genetik yang telah dilakukan sebelumnya, yaitu pada kelompok C, khususnya sub-kelompok $\mathrm{C}_{2}$. Sementara itu, isolat CSU juga mempunyai rata-rata tingkat infeksi (patogenitas) yang tidak berbeda nyata dengan isolat CLP yang mana mempunyai rata-rata tingkat infeksi berturut-turut 0,63 dan 0,63 (Tabel 3). Pada analisis genetik isolat CSU berada pada kelompok yang sama dengan isolat CLP, yaitu pada kelompok B (Gambar 2 dan Tabel 1). Isolat CKB berada pada satu kelompok dengan isolat CSS dan CJB, namun demikian isolat CKB mempunyai rata-rata tingkat infeksi yang berbeda nyata dengan isolat CSS dan CJB. Hal ini menunjukkan bahwa kemungkinan besar isolat CKB berbeda secara perilaku (karakteristik) patogenitasnya dengan isolat CSS dan CJB walaupun secara genetik berdekatan. Hal ini juga menjadi dasar untuk menempatkan isolat CKB pada sub-kelompok yang berbeda dengan isolat CSS dan CJB, yaitu subkelompok $\mathrm{C}_{1}$.

Isolat $\mathrm{CBK}$ mempunyai rata-rata tingkat infeksi (patogenitas) yang berbeda nyata dengan isolat-isolat yang lain, yaitu 3,19 . Hal ini selaras dengan hasil analisis genetik, yang mana isolat CBK merupakan kelompok tersendiri dibanding-kan dengan kelompok yang lain, yaitu termasuk ke dalam kelompok A (Gambar 2 dan Tabel 1). Demikian juga dengan isolat CJT yang mempunyai rata-rata tingkat infeksi (patogenitas) yang berbeda nyata dengan isolat-isolat yang lain, dan relevan dengan hasil analisis genetik yang menempatkan isolat CJT pada kelompok tersendiri yaitu kelompok D (Gambar 3 dan Tabel 1). Isolat CJT mempunyai rata-rata tingkat infeksi tertinggi dibandingkan dengan isolat-isolat yang lain, yaitu 3,70. Hal ini menjadi dasar untuk menempatkan isolat CJT sebagai kelompok isolat atau ras yang paling virulen.

Penelitian Nghia et al. (2007) mengenai diferensiasi isolat Corynespora cassiicola dari perkebunan karet di Malaysia menggunakan marker ISSR, melaporkan bahwa terdapat 3 ras Corynespora cassiicola yang dihasilkan dari analisis genetik pada penelitian tersebut. Beberapa daun yang digunakan pada uji kelayuan daun pada penelitian tersebut, sama dengan yang digunakan dalam penelitian ini, yaitu daun klon PB 260 dan RRIM 600. Hasil penelitian Nghia et al. (2007) menunjukkan bahwa klon PB 260 mengalami infeksi ringan terhadap isolat Corynespora Ras 1, terinfeksi berat terhadap Ras 2, dan terinfeksi moderat terhadap Ras 3. Sementara itu pada penelitian tersebut, klon RRIM 600 mengalami infeksi ringan terhadap Ras 3, infeksi berat terhadap Ras 1 dan infeksi moderat terhadap Ras 2. Berbeda pada penelitian ini, dimana hasil analisis genetik isolat Corynespora dari perkebunan karet di Indonesia menggunakan marker ISSR menghasilkan empat ras Corynespora. Uji kelayuan daun pada klon PB 260 dalam penelitian ini menunjukkan bahwa daun PB 260 mengalami infeksi ringan terhadap isolat dari Lampung dan Sumatera Utara (Ras 2), serta Kalimantan Barat (Ras 3); mengalami infeksi berat terhadap isolat dari Bengkulu (Ras 1) dan Jawa Tengah (Ras 4); dan mengalami infeksi moderat terhadap isolat dari Sumatera Selatan dan Jambi (Ras 3). Sementara itu klon RRIM 600 dalam penelitian ini mengalami infeksi ringan terhadap isolat dari Lampung dan Sumatera Utara (Ras 2); mengalami infeksi berat terhadap isolat dari Bengkulu (Ras 1) dan Jawa Tengah (Ras 4); dan mengalami infeksi moderat terhadap isolat dari Jambi, Sumatera Selatan, dan Kalimantan Barat (Ras 3). Bervariasinya hasil yang didapat dari penelitian ini dibandingkan dengan hasil penelitian Nghia et al. (2007) dimungkinkan karena perbedaan asal isolat, dimana pada penelitian Nghia et al. (2007) isolat Corynespora diambil dari klon yang sebagian besar adalah klon RRIM, sedangkan pada penelitian ini seluruh isolat diambil dari klon GT 1.

\section{Respons Klon Karet terhadap Infeksi 7 Isolat C. Cassiicola pada Uji Kelayuan Daun}

Rata-rata tingkat infeksi tujuh isolat C.cassiicola terhadap beberapa klon karet pada uji kelayuan daun dapat menggambarkan respons klon-klon karet tersebut terhadap 7 sampel isolat yang digunakan. 
Analisis keragaman genetik isolat Corynespora cassiicola (Berk \& Curt) Wei. di Indonesia menggunakan marker ISSR (Inter Simple Sequence Repeat)

Tabel 3.Tingkat infeksi tujuh isolat Corynespora cassiicola pada daun karet dari berbagai klon Table 3. Pathogenicity level of seven Corynespora isolates on leaves of various rubber clones

\begin{tabular}{|c|c|c|c|c|c|c|c|c|c|c|}
\hline \multirow{2}{*}{$\begin{array}{l}\text { Isolat } \\
\text { Isolates }\end{array}$} & \multicolumn{9}{|c|}{$\begin{array}{l}\text { Rata-rata skor infeksi Corynespora pada daun karet berbagai klon } \\
\text { Average score of Corynespora pathogenicity on leaves of various rubber clones }\end{array}$} & \multirow{2}{*}{$\begin{array}{l}\text { Rata-rata }{ }^{1)} \\
\text { Average }\end{array}$} \\
\hline & $\begin{array}{c}\text { BPM } \\
24 \\
\end{array}$ & $\begin{array}{c}\text { IRR } \\
5\end{array}$ & $\begin{array}{c}\text { RRIM } \\
712 \\
\end{array}$ & $\begin{array}{c}\text { RRIC } \\
100 \\
\end{array}$ & $\begin{array}{c}\text { PB } \\
260 \\
\end{array}$ & $\begin{array}{l}\text { IRR } \\
118 \\
\end{array}$ & $\begin{array}{c}\text { RRIM } \\
600 \\
\end{array}$ & $\begin{array}{l}\text { IRR } \\
107 \\
\end{array}$ & $\begin{array}{c}\text { PR } \\
255\end{array}$ & \\
\hline CBK & 4,00 & 1,67 & 1,00 & 3,67 & 3,67 & 3,33 & 4,00 & 3,33 & 4,00 & $3,19 \mathrm{~d}$ \\
\hline CLP & 0,67 & 1,00 & 0,67 & 0,67 & 1,00 & 0,67 & 0,33 & 0,00 & 0,67 & $0,63 \mathrm{~b}$ \\
\hline CSU & 0,67 & 1,33 & 1,00 & 0,67 & 0,33 & 0,33 & 1,00 & 0,00 & 0,33 & $0,63 \mathrm{~b}$ \\
\hline CKB & 0,33 & 0,33 & 0,00 & 0,33 & 0,33 & 0,33 & 0,00 & 0,00 & 0,33 & $0,22 \mathrm{a}$ \\
\hline CSS & 2,00 & 1,00 & 2,33 & 1,33 & 1,67 & 1,33 & 2,00 & 1,00 & 2,67 & $1,70 \mathrm{c}$ \\
\hline CJB & 2,67 & 0,00 & 0,00 & 1,67 & 2,00 & 0,67 & 2,33 & 3,00 & 2,33 & $1,63 \mathrm{c}$ \\
\hline CJT & 4,00 & 4,00 & 4,00 & 2,00 & 3,67 & 4,00 & 3,67 & 4,00 & 4,00 & $3,70 \mathrm{e}$ \\
\hline $\begin{array}{l}\text { Rata-rata } \\
\text { Average }\end{array}$ & 2,05 & 1,33 & 1,29 & 1,48 & 1,81 & 1,52 & 1,90 & 1,62 & 2,05 & \\
\hline
\end{tabular}

1) Angka-angka yang diikuti huruf yang sama pada kolom yang sama tidak berbeda nyata berdasarkan uji Duncan taraf 5\% (Figures followed by the same letters at the same coloum are not significantly different based at 5\% Duncan test level)

Keparahan infeksi (pathogenicity severity):

skor 0 : jika tidak ada luka/bercak; (no injury or spots found)

skor 1 : jika ada perubahan warna menjadi gelap namun kecil; (if there are changes to a darker color but smaller)

skor 2 : jika terdapat bercak yang besar tanpa meluas melalui urat-urat daun; (large patches seen but not extending to the leafveins)

skor 3 : jika terdapat bercak yang besar dan meluas pada urat-urat daun; (great spots found and extending to the leafveins)

skor 4 : jika terdapat bercak yang besar dan menonjol dengan adanya miselium; (large and prominent spots found due to the presence of mycelium)

Hasil uji kelayuan daun menunjukkan bahwa pada umumnya klon-klon karet yang digunakan dalam uji tersebut mempunyai respons yang hampir sama antara klon yang satu dengan klon yang lainnya. Namun demikian dari hasil uji tersebut diketahui bahwa tingkat infeksi tujuh isolat Corynespora pada daun karet klon RRIM 712 dan IRR 5 berbeda nyata dengan tingkat infeksi pada daun karet klon PR 255 dan BPM 24, yang mana tingkat infeksi Corynespora pada klon RRIM 712 dan IRR 5 lebih rendah dibanding klon PR 255 dan BPM 24 (Tabel 4). Penampakan infeksi Corynespora secara umum pada daun IRR 5 berupa bercak yang berwarna gelap, tidak meluas pada urat-urat daun, dan tidak terlihat adanya miselium. Sementara itu penampakan infeksi Corynespora pada daun PR 255 dan BPM 24 berupa bercak gelap meluas melalui urat-urat daun dan tepian daun (Gambar 4).

Tingkat infeksi tujuh isolat Corynespora pada daun karet klon RRIC 100 berbeda nyata dengan tingkat infeksi pada daun karet klon RRIM 600, yang mana tingkat infeksi Corynespora pada klon RRIC 100 lebih rendah dibandingkan klon RRIM 600 (Tabel 4). Penampakan daun pada saat terjadinya infeksi Corynespora pada daun RRIC 100 tidak jauh berbeda dengan penampakan daun IRR 5. Sementara itu penampakan infeksi pada daun RRIM 600 berupa bercak gelap tidak meluas pada uraturat daun, tetapi bercak-bercak cukup banyak, dan meluas pada bagian tepi daun (Gambar 4). 



Skala (score) 0 (a); 1 (b); 2 (c); 3 (d); 4 (e)

Gambar 3. Skala bercak daun pada uji kelayuan daun Figure 3. Scale of leaf spot in withered leaf test 
Analisis keragaman genetik isolat Corynespora cassiicola (Berk \& Curt) Wei. di Indonesia menggunakan marker ISSR (Inter Simple Sequence Repeat)

Tabel 4. Rata-rata tingkat infeksi tujuh isolat C.cassiicola pada daun klon yang diuji Table 4. Average pathogenicity levels of seven isolates of C. cassicola in leaves test clones

\begin{tabular}{lc}
\hline Klon & $\begin{array}{c}\text { Rata-rata skor infeksi tujuh isolat Corynespora }{ }^{1)} \\
\text { Average of pathogenicity score of seven Corynespora isolates }{ }^{1)}\end{array}$ \\
\hline RRIM 712 & $1,29 \mathrm{a}$ \\
IRR 5 & $1,33 \mathrm{a}$ \\
RRIC 100 & $1,48 \mathrm{ab}$ \\
IRR 118 & $1,52 \mathrm{ab}$ \\
IRR 107 & $1,62 \mathrm{abc}$ \\
PB 260 & $1,81 \mathrm{bcd}$ \\
RRIM 600 & $1,90 \mathrm{~cd}$ \\
PR 255 & $2,05 \mathrm{~d}$ \\
BPM 24 & $2,52 \mathrm{~d}$ \\
\hline
\end{tabular}

1) Angka-angka yang diikuti huruf yang sama pada kolom yang sama tidak berbeda nyata berdasarkan uji Duncan taraf $5 \%$ (Figures followed by the same letters at the same coloum are not significantly different based on 5\% Duncan test level)

Keparahan infeksi (pathogenicity severity):

skor 0 : jika tidak ada luka/bercak; (no injury or spots)

skor 1 : jika ada perubahan warna menjadi gelap namun kecil; (color changes to a darker color but smaller)

skor 2 : jika terdapat bercak yang besar tanpa meluas melalui urat-urat daun; (large patches seen but not extending to the leaf veins)

skor 3 : jika terdapat bercak yang besar dan meluas pada urat-urat daun; (great spots found, extending to the leafveins)

skor 4: jika terdapat bercak yang besar dan menonjol dengan adanya miselium; (large and prominent spots found due to the presence of mycelium)

Secara umum klon uji yang digunakan dalam penelitian ini, berdasarkan hasil uji respons terhadap infeksi Corynespora pada Tabel 4, dapat dikategorikan dalam kategori resisten sampai dengan sedang. Hasil tersebut selaras dengan hasil penelitian lapangan resistensi klon terhadap Corynespora pada penelitian-penelitian terdahulu. Meskipun demikian, beberapa klon menunjukkan respons yang berbeda dari hasil penelitian resistensi di lapangan seperti klon RRIM 712, RRIM 600, dan PR 255 (Tabel 5).

Dalam penelitian ini, klon RRIM 712 mempunyai tingkat infeksi Corynespora paling rendah dibanding klon-klon yang lain, tetapi berdasarkan uji resistensi klon di lapangan oleh Situmorang et al. (2005) dan Munir et al. (2009), RRIM 712 termasuk dalam kategori yang kurang resisten terhadap Corynespora. Demikian juga dengan RRIM 600, dimana pada penelitian ini mempunyai tingkat infeksi Corynespora rendah-sedang, tetapi pada uji resistensi di lapangan termasuk dalam kategori buruk. Sementara itu, klon PR 255 dalam penelitian ini mempunyai tingkat infeksi Corynespora sedang, sedangkan pada uji resistensi di lapangan, PR 255 mempunyai resistensi terhadap Corynespora yang sangat baik (Tabel 5).

Perbedaan resistensi klon karet seperti RRIM 712, RRIM 600, dan PR 255 terhadap Corynespora dalam penelitian ini dibandingkan dengan uji resistensi yang dilakukan Situmorang et al. (2005) dan Munir et al. (2009) di lapangan adalah dikarenakan pada uji resistensi di lapangan yang dilakukan oleh Situmorang et al, (2005) dan Munir et al. (2009) menggunakan 1 sumber patogen yaitu Corynespora asal Sumatera Selatan, karena penelitian tersebut dilakukan di Sumatera Selatan. Sementara itu, pada uji respons klon 

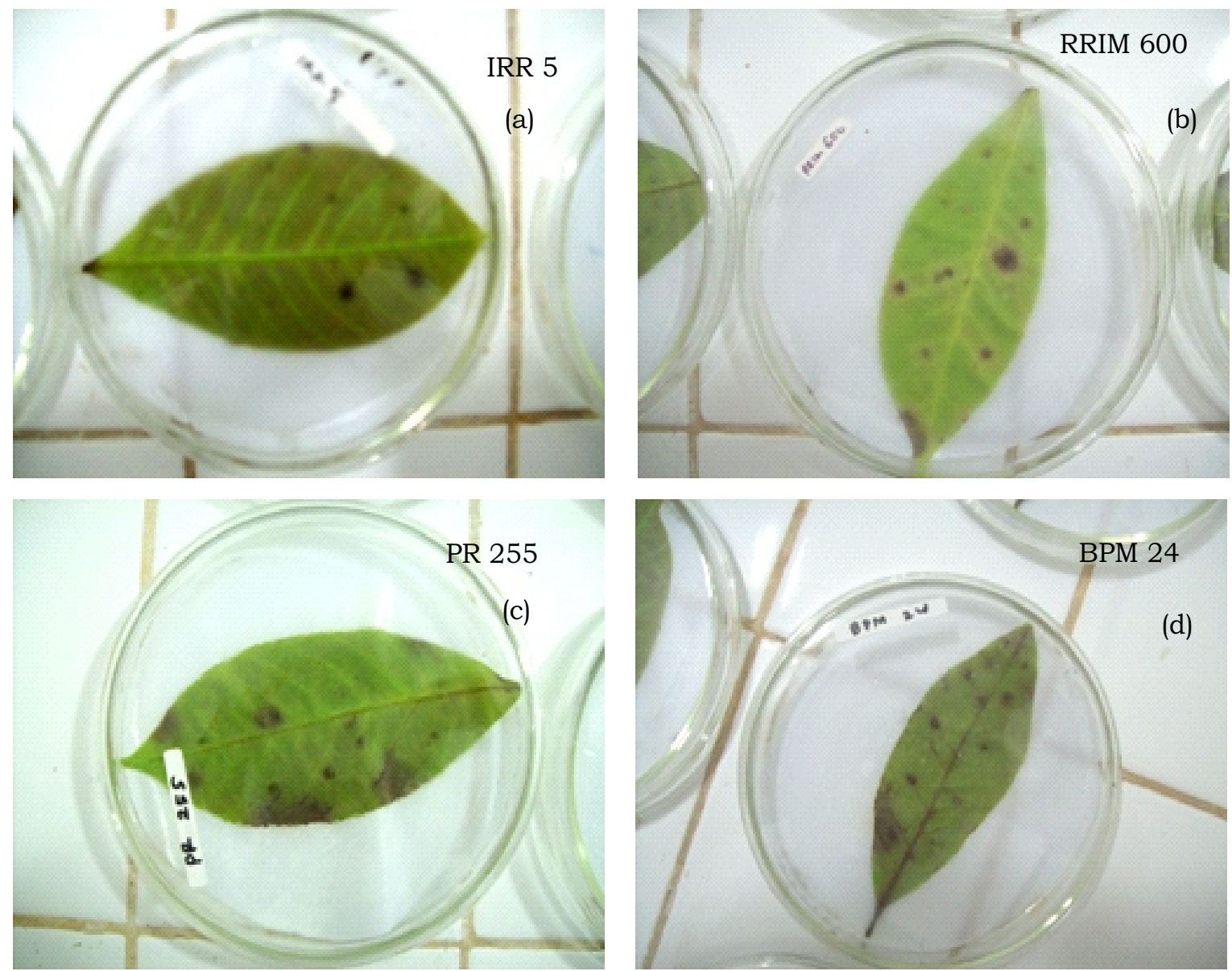

Gambar 4. Bercak infeksi Corynespora pada daun

Figure 4. Phatogenicity spot of Corynespora on leaves

Tabel 5. Resistensi klon karet terhadap penyakit Corynespora di lapangan Table 5. Rubber clone resistency to Corynespora disease in the field

\begin{tabular}{lc} 
Klon & $\begin{array}{c}\text { Resistensi terhadap Corynespora } \\
\text { Resistency to Corynespora }\end{array}$ \\
\hline RRIM 712 & kurang \\
IRR 5 & sangat baik \\
RRIC 100 & baik \\
IRR 118 & sangat baik \\
IRR 107 & baik \\
PB 260 & baik \\
RRIM 600 & buruk \\
PR 255 & sangat baik \\
BPM 24 & sedang \\
\hline
\end{tabular}

Sumber (source) : diolah dari Situmorang et al.(2005) dan Munir et al. (2009) 
terhadap infeksi Corynespora dalam penelitian ini adalah menggunakan tujuh isolat Corynespora asal tujuh wilayah yang berbeda, sehingga hasil penelitian ini lebih menggambarkan respons klon terhadap Corynespora secara komprehensif berkaitan dengan asal patogen dan/atau ras patogen, dimana respons klon terhadap Corynespora dapat berbeda-beda antara Corynespora dari suatu daerah/ras dengan Corynespora dari daerah/ras yang lain. Hal ini berkaitan dengan patogenitas Corynespora, dimana toksin yang disebut sebagai cassiicolin adalah faktor penentu utama.

Menurut Breeton et al. (2000), dalam interaksi $H$. brasiliensis dan C. cassiicola, antara klon resisten dan rentan tidak terdapat perbedaan kecepatan penetrasi cendawan. Artinya patogen yang sama (1 ras) memiliki kemampuan untuk menembus lapisan permukaan daun, baik pada klon resisten maupun klon rentan dan kemudian masuk ke dalam jaringan tanaman. Oleh karena itu, dapat dipahami bahwa ketebalan kutikula, epidermis ataupun pembentukan lapisan lignin pada dinding sel bukan merupakan mekanisme yang digunakan klon karet resisten untuk bertahan terhadap serangan patogen tersebut.

Perbedaan nyata antara respons klon resisten dan rentan terlihat pada invasi cendawan dalam jaringan tanaman. Serangan pada klon rentan menyebabkan kerusakan pada sel epidermis, nukleus, dan organel lainnya, sehingga akhirnya menimbulkan kerusakan parah pada daun. Pada klon resisten kolonisasi cendawan terbatas hanya pada beberapa sel di sekitar hifa. Kondisi tersebut menimbulkan dugaan bahwa klon resisten memiliki suatu molekul yang disandikan oleh suatu gen tertentu, sehingga mampu mengenal atau langsung mengatasi perkembangan cendawan (Nurhaimi, 2006). Hal ini diperkuat oleh kenyataan bahwa ketika menginfeksi tanaman karet, C. cassiicola mengeluarkan toksin (cassiicolin) (Onesirosan et al., 1975; Liyanage dan Liyanage 1986; Purwantara 1987; Suwarto 1989; Breton et al., 1996; Breton et al., 2000). Toksin ini diduga merupakan faktor penentu utama dalam patogenisitas C. cassiicola. Cassiicolin merupakan Host-selective toxins (HST), termasuk dalam kelompok glikoprotein dengan bobot molekul sekitar $21 \mathrm{kDa}$ (Breton dan d'Auzac, 1999).

Menurut Nurhaimi (2006), mekanisme resistensi daun karet terhadap C. cassiicola adalah berkaitan dengan kemampuan tanaman untuk mengatasi penyebaran toksin. Kemampuan tanaman resisten mengatasi penyebaran toksin melalui aktivasi gen telah dilaporkan pada interaksi antara tanaman jagung yang memiliki alel dominan pada lokus Hm 1 dengan cendawan patogen Cochliobolus carbonum Ras 1. Gen Hm1 menyandikan karbonil reduktase, HC-toxin reductase (HCTR) (Johal dan Briggs, 1992) yang menginaktifkan toksin yang diproduksi oleh C. carbonum melalui reduksi enzimatik (Meeley et al., 1992; Meeley dan Walton 1991). Genotipe homozigot hm $1 \mathrm{hm} 1$ tidak memiliki aktivitas HCTR, ternyata rentan terhadap C. carbonum ras 1 .

Pada klon karet rentan yang terinfeksi, berlanjutnya gejala penyakit diduga berhubungan dengan ketidakmampuan klon tersebut mengatasi penyebaran toksin (Nurhaimi, 2006). Konidia C. cassiicola biasanya akan berkecambah dalam waktu 4 jam (Chee, 1988) dan penetrasi fungi terjadi 12 jam setelah inokulasi (Breton et al., 2000). Pada klon rentan, pengaruh toksin terjadi dalam waktu yang relatif singkat, sekitar 24 jam setelah patogen diinfeksikan ke daun tanaman (Breton et al., 1996). Menurut Nurhaimi (2006), hal tersebut sejalan dengan pengamatan makroskopis pada hari ke-1 yaitu 24 jam setelah inokulasi tidak menunjukkan adanya gejala, namun secara mikroskopis melalui pengamatan anatomi daun telah terjadi kerusakan pada lapisan kutikula dan epidermis bawah daun. Kerusakan tersebut berlanjut pada sebagian parenkima bunga karang. Pada hari ketiga kerusakan lapisan jaringan daun semakin banyak, dimana lapisan parenkima bunga karang hancur dan kerusakan terjadi pada sebagian lapisan parenkima palisade. 


\section{KESIMPULAN}

Hasil analisis keragaman genetik isolat Corynespora cassiicola asal tujuh wilayah sentra karet di Indonesia menggunakan marker ISSR menghasilkan empat kelompok (4 ras) C. cassiicola, kelompok A (Ras 1) yaitu isolat asal Bengkulu, kelompok B (Ras 2) meliputi isolat asal Lampung dan Sumatera Utara, kelompok C (Ras 3) meliputi isolat asal Kalimantan Barat, Sumatera Selatan dan Jambi, dan kelompok D (Ras 4) yaitu isolat asal Jawa Tengah. Hasil uji kelayuan daun menunjukkan bahwa isolat-isolat Corynespora yang berada pada kelompok yang sama berdasarkan hasil analisis genetik, juga mempunyai tingkat infeksi (patogenitas) yang sama terhadap beberapa daun karet yang diuji. Isolat asal Jawa tengah (CJT) mempunyai rata-rata tingkat infeksi (patogenitas) tertinggi dibanding isolat yang lainnya. Tingkat infeksi tujuh isolat Corynespora terendah adalah pada klon RRIM 712 dan IRR 5, sedangkan tingkat infeksi tujuh isolat Corynespora tertinggi terdapat pada klon BPM 24 dan PR 255.

\section{UCAPAN TERIMA KASIH}

Penulis mengucapkan terima kasih kepada Dr. Aron Situmorang, atas kerja samanya dalam penyiapan isolat Corynespora yang digunakan dalam penelitian ini.

\section{DAFTAR PUSTAKA}

Breton, F., J. d'Auzac, D. Garcia, C. Sanier, and J.M. Esbach. 1996. Recent research on Corynespora cassiicola. Proc. of Workshop on Corynespora Leaf Fall Disease of Hevea Rubber. Medan, December $16^{\text {th }}-17^{\text {th }} 1996.49-78$.

Breton, F. and J. d'Auzac. 1999. Cassiicolin, a host-selective toxin produced by Corynespora cassiicola, causal agent of Hevea leaf fall disease. International Rubber Research Development Board Meeting, Haicau, Chinese People's Republic, 18-22 October 1999.

Breton, F., C. Sanier, and A. J. d'Auzac. 2000. Role of cassiicolin, a hostselective toxin, in pathogenicity of Corynespora cassiicola, causal agent of a leaf fall disease of Hevea. J. Rubb.Res. 3(2), 115-128.
Burgess, T., M. J. Wingfield and B. W. Wingfield. 2001. Simple sequence repeat markers distinguish among morphotypes of Sphaeroptis sapinea. Applied and Environmental Microbiology, 67(1), 354-362.

Chee, K. H. 1988. Studies on sporulation, pathogenicity and epidemiology of Corynespora cassiicola on Hevea rubber. J. Nat. Rubb. Res., 3(1), 21-29.

Darmono, T. W, A. Darussamin, and S. Pawirosoemardjo. 1996. Variation among isolates of Corynespora cassiicola associated with Hevea brasiliensis in Indonesia. Proc. Workshop on Corynespora Leaf Fall Disease of Hevea Rubber. Medan. $16^{\text {th }}$ $17^{\text {th }}$ December 1996. 79-91.

Gil-Lamaignere, C. E., Roilides, J. Hacker and F. M. C. Muller. 2003. Molecular typing for fungi a critical review of the possibilities and limitation of currently and future method. Clin Microbiol. Infect., 9, 172-185.

Johal, G. S. and S. P. Briggs. 1992. Reductase activity encoded by the $H m 1$ disease resistance gene in maize. Science. 258, 985-987.

Liyanage, N. I. S., and A. S. Liyanage. 1986. A study on the production of a toxin in Corynespora cassiicola. J. Rubb. Res. Inst. Sri Lanka., 65, 51-53.

McDonald, B. A. 1997. The population genetics of fungi: tool and techniques. Phytophatology., 87, 448-453.

Meeley, R. B., G. S. Johal, S. P. Briggs, and I. D. Walton. 1992. A biochemical phenotypefor a disease resistance gene of maize. Plant Cell., 4, 71-77.

Meeley, R. B. and Walton J. D. 1991. Enzymatic detoxification of HC-toxin, the hostselectivecyclic peptide from Cochliobolus carbonum. Plant Physiol., 97,1080-1086. 
Munir, M., H. Suryaningtyas, A. Situmorang, dan T. R. Febbyanti. 2009. Resistensi klon IRR Seri 100 terhadap penyakit gugur daun Corynespora dan Colletotrichum. Pros. Lok. Nas. Pemuliaan Tanaman Karet 2009. Batam, 4-6 Agustus 2009. 262-268.

Nei, M. and W. H. Li. 1979. Mathematical model for studying genetic variation in terms of restriction endonucleases. Proc. Nat. Academy of Sciences of the United States of America. 76, 52695273.

Nghia, N. A., J. Kadir, A. Malik, M. P. Abdullah, E. Sunderasan and S. Napis. 2007. Differentiating Corynespora cassiicola isolated from Hevea plantation in Malaysia using Inter Simple Sequence Repeat (ISSR) Markers. International Rubber Conference 2007, Natural Rubber Industry: R\&D Achievements \& Challenges, 12-13 November 2007, Siem Reap, Cambodia, 435-445.

Nurhaimi. 2006. Ekspresi gen-gen responsif terhadap Corynespora cassiicola pada tanaman karet (Hevea brasiliensis, Muell. Arg.). Disertasi. Sekolah Pascasarjana Institut Pertanian Bogor, www.repository. ipb.ac.id Diakses tanggal 4 Mei 2012.

Onesirosan, P. T., C. T. Mabuni, R. D. Durbin R. D., R. B. Morin, D. H. Rich, and D. C. Arny. 1975. Toxin production by Corynespora cassiicola. Physiological Plant Pathology., 5, 289-295.

Purwantara, A. 1987. Studi histologi daun karet yang terserang Corynespora cassiicola (Berk. \& Curt.) Wei. Menara Perkebunan. 55, 47-49.

Ramli, O., B. Masahuling, S.H. Ong and H. Ismail. 1996. Strategies and development of resisteant Hevea clones against Corynespora leaf fall. Proc. Workshop on Corynespora Leaf Fall Disease of Hevea Rubber, Medan, $16^{\text {th }}$ $17^{\text {th }}$ December 1996. 177-194.
Rohlf, F. J. 1993. NTSYS-pc. Numerical taxonomy and multivariate analisis system. Exeter software, New York

Sambrook, J. E. F. Fritsch and Maniatis. 1989. Molecular cloning : a laboratory manual Cold. Spring Harbor Laboratory Press. Cold Spring Harbor, New York.

Sinulingga, W., Suwarto and H. Soepena. 1996. Current status of Corynespora leaf fall in Indonesia, Proc. workshop on Corynespora Leaf Fall Disease of Hevea Rubber, 16-17 December 1996, Medan, Indonesia, 29-36.

Situmorang, A. 2002. Sebaran penyakit gugur daun, virulensi, dan genetika Corynespora cassiicola asal sentra perkebunan karet Indonesia. Disertasi, Program Pasca Sarjana, Institut Pertanian Bogor.

Situmorang, A., M. Lasminingsih, dan T. Wijaya. 2005. Resistensi klon karet anjuran dan strategi penggunaanya dalam pengendalian penyakit penting di perkebunan karet. Pros. Lok. Nas. Pemuliaan Tanaman Karet 2005, Medan, 22-23 November 2005. 141156.

Suwarto. 1989. Patogenisitas dan pembentukan toksin isolat Corynespora cassiicola dari tanaman karet (Hevea brasiliensis) dan kedelai. Risalah Seminar Latihan/Magang, 5559.

William, J. G. K., A. R. Kubelik, K. J. Livak, J. A. Rafalski and S.V. Tingey. 1990. DNA polymorphism amplified by arbitrary primers are useful as genetic markers. Nucleid Acid Res., 18. 